\title{
O Sabão na Luta Contra o SARS-CoV-2: Uma Questão de Forças Intermoleculares
}

$>$

M. Soledade C. S. Santos

\begin{abstract}
Soap in the fight against SARS-CoV-2: it's all about intermolecular forces. Soaps and SARS-CoV-2 virus envelope chemical composition are presented. The amphiphilic characteristics of detergents and viral envelope lipid components are responsible for the establishment of strong detergent-lipid intermolecular interactions that trigger the destruction of the viral envelope leading to inactivation of the virus. The concentrations of soap/alcohol necessary to ensure epidermis wettability are presented, since this process is cornerstone for an effective inactivation of SARS-CoV-2. Intermolecular interactions between amphiphilic molecules explain the efficiency and importance of regular hands and surfaces hygiene in the fight against the COVID-19 pandemic.
\end{abstract}

A composição química dos sabões e do envelope do vírus SARS-CoV-2 são apresentados. As características anfifílicas dos componentes dos detergentes e dos lípidos do envelope viral são responsáveis pelo estabelecimento de fortes interações intermoleculares detergente-lípido que permitem a destruição do envelope viral levando à inativação do vírus. As concentrações de sabão/álcool necessárias para assegurar a molhabilidade da epiderme, por forma a permitir a completa remoção e inativação do SARS-CoV-2, são apresentadas. As interações intermoleculares entre moléculas anfifílicas permitem explicar a importância e eficácia de uma higiene regular das mãos e superfícies no combate à pandemia de COVID-19.
0 velho sabão, conhecido desde a Antiguidade, e usado pelo Homem há mais de 4 mil anos, volta à ribalta no contexto da luta contra a pandemia da COVID-19 no séc. XXI. A lavagem regular das mãos com sabão está entre as principais medidas de prevenção da contaminação com o vírus SARS-CoV-2 preconizadas pela Organização Mundial de Saúde, OMS, (Figura 1) [1], mas porquê?

O sabão, obtido fervendo gorduras com cinzas, é conhecido desde 2800 a.C. na Mesopotâmia. Contudo, a designação de sabão está habitualmente associada às escorrências observadas no rio Tibre, após sacrifícios animais no Monte Sapo, cuja eficiência de lavagem foi reconhecida pelos Romanos. A saponificação de gorduras, esquematicamente apresentada na Figura 2, leva à formação de misturas de sais de ácidos gordos, que apresentam propriedades anfifílicas (gostam de ambos: água e óleo) e cujas soluções aquosas têm capacidade de solubilização de gorduras.
Figura 1 - Infografia da OMS sobre a importância da lavagem das mãos no combate à doença.

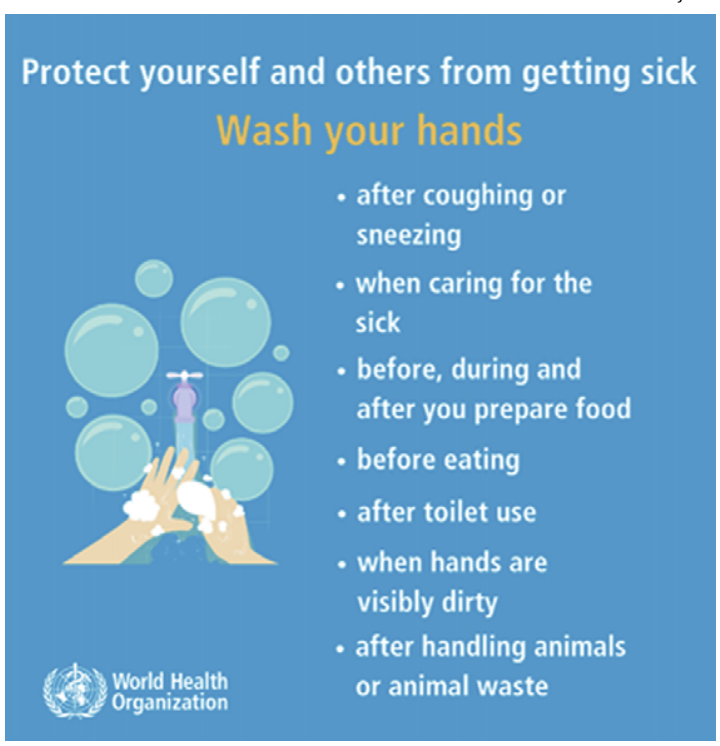


Figura 2 - Esquema da saponificação de gorduras com formação de sabão: sais de ácidos gordos e glicerol.<smiles>[R]C(=O)OCC(COC([R])=O)OC([R7])=NOC(=O)O</smiles>

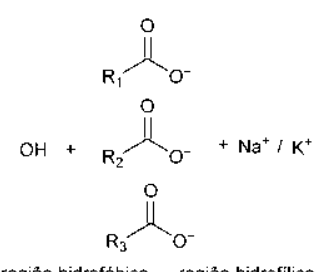

regiảo hidrofóbica --- regiảo hidroflica
Estas propriedades anfifilicas estão na base da capacidade dos sabões para inativar os Coronavírus, como o SARS-CoV-2, por interações intermoleculares entre os compostos anfifílicos do sabão e da camada externa dos vírus desta família.

Os vírus podem ser descritos, em termos muito simples, como nanopartículas de ácido nucleico, DNA ou RNA, contido num invólucro proteico denominado capsídeo. Os Coronavírus, responsáveis por infeções respiratórias no Homem, outros mamíferos e aves, têm cerca de 100 nm de diâmetro e o seu capsídeo está envolvido por uma bicamada lipídica que forma um envelope protetor adicional (Figuras 3,4) [2-4]. Este envelope lipídico auto-montado, é assegurado essencialmente por forças de dispersão entre fosfolípidos (anfifilicos) e protege uma estrutura viral assente em interações intermoleculares fracas, mas é, também, um ponto de vulnerabilidade do SARS-CoV-2, perante outras moléculas anfifílicas, como as constituintes dos sabões, géis de banho, detergentes de lavagem de roupa, loiça ou superfícies.

A composição química da vasta gama de produtos de higiene e limpeza é muito variada em termos dos tipos moléculas e proporções dos tensioativos, vulgo

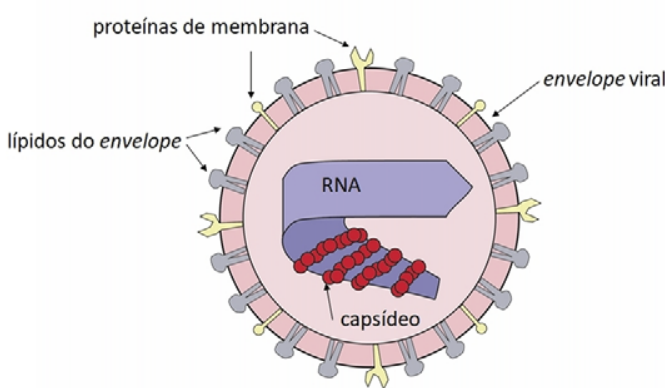

Figura 4 - Representação esquemática da estrutura do SARS-CoV-2 (adaptado de [4]).

detergentes, presentes nas diversas formulações. Independentemente da sua composição química específica, os produtos de higiene e limpeza são predominantemente constituídos por compostos anfifílicos como o sabão (tensioativos iónicos e/ou não iónicos). A afinidade dos compostos anfifílicos para a bicamada lipídica e o estabelecimento de ligações intermoleculares detergente-lípido, levam à intercalação de moléculas de detergente na bicamada lipídica com a consequente destruição da integridade do envelope protetor, resultando na inativação do vírus (Figura 5). A nível molecular trata-se de um fenómeno idêntico à dissolução de gotículas de gordura em agregados moleculares de tensioativos, que explica o vulgar processo de lavagem $[5,6]$.

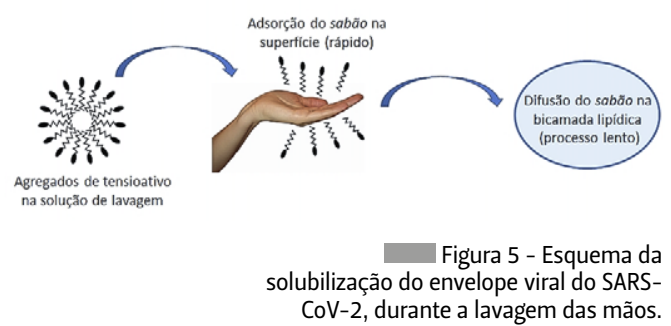

Mas porquê 20 segundos de lavagem das mãos? É necessário garantir que toda a superfície cutânea é eficazmente molhada e ensaboada de forma a permitir a solubilização da bicamada lipídica do envelope viral. Este processo não é instantâneo, e é indispensável para assegurar a completa inativação e remoção do SARS-CoV-2. A epiderme, camada exterior da pele, protege o corpo das agressões externas, segregando lípidos e proteínas, e conferindo-Ihe características de molhabilidade muito particulares. É hoje reconhecido que a pele tem características hidrofóbicas, sendo a hidrofobicidade cutânea dependente da zona do corpo, pelo que a avaliação de cosméticos e tratamentos dérmicos implica a determinação de tensões superficiais críticas de Zisman [6,7]. A tensão superficial crítica avalia o valor 
mínimo que é necessário a tensão superficial da solução de lavagem atingir para assegurar o seu espalhamento sobre a superfície da pele. Este valor define assim qual a tensão superficial que toda e qualquer solução de higienização tem de ter para garantir que a pele é molhada por forma a permitir a remoção, ou mais corretamente, a inativação de vírus, bactérias ou outros contaminantes da nossa pele. 0 valor situa-se entre 24 e $27 \mathrm{mNm}^{-1}$ na região dos braços e mãos $[7,8]$.

As soluções aquosas de sabão com concentrações inferiores a $10 \mathrm{mM}$ atingem tensões superficiais desta ordem de grandeza, sendo, portanto, muito eficazes nos processos de lavagem. Os álcoois também são moléculas anfifilicas tendo a capacidade de se introduzir entre os lípidos do envelope do SARS-CoV-2, contudo, a sua eficácia a baixas concentrações é mais reduzida pois para se atingirem tensões superficiais de $25 \mathrm{mNm}^{-1}$, a $25^{\circ} \mathrm{C}$, é necessário usar soluções aquosas de etanol a $70 \%$ ou de isopropanol a $40 \%$ [9] (Figura 6).

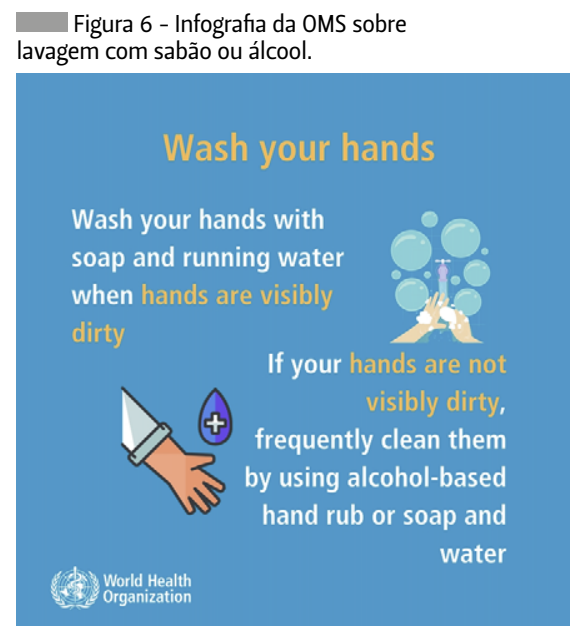

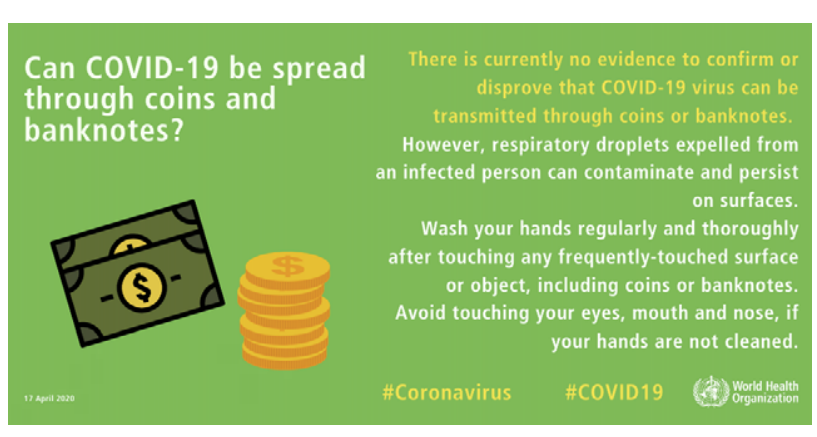

Figura 7 - Infografia da OMS sobre contaminação de superfícies.

Os estudos sobre o tempo de residência do SARS-CoV-2 em superfícies são escassos, refletem condições extremas de contaminação e são pouco representativos, devendo ser encarados como meramente indicativos (Figura 7). Os resultados apontam tempos de meia vida do vírus de 6 a 7 horas em materiais plásticos e aço inoxidável e inferiores a 4 horas em cartão [10]. Neste contexto, exceto para materiais muito hidrofóbicos como o Teflon, a limpeza regular de superfícies e vestuário com soluções aquosas de detergente asseguram a inativação do SARS-CoV-2. Assim, uma limpeza prévia de equipamentos de utilização comum com um papel embebido numa solução alcoólica de composição adequada, sempre que não é possível recorrer à lavagem clássica, é uma abordagem segura para uma utilização partilhada em espaços públicos como escolas, refeitórios, ginásios, ou salas de espetáculos.

Contudo, e independentemente da baixa absorção cutânea destes produtos de limpeza [8], convém ter presente que a aplicação frequente e continuada deste tipo de produtos pode levar a irritações/fissuras cutâneas, resultantes essencialmente da falta de lubrificação da epiderme, pelo que é recomendável acompanhar as lavagens frequentes com a aplicação regular de cremes hidratantes.

\section{Referências}

[1] World Health Organization em https://www.who.int/emergencies/diseases/novel-coronavirus-2019, acedido em 21/04/2020.

[2] S. M. Poutanen, 222 Human Coronaviruses, 1117-1120e4, in S. Long, L. K.Pickering and C. G. Prober (Ed.) Principles and Practice of Pediatric Infectious Diseases, Part II Etiologic Agents of Infectious Diseases, $4^{\text {th }}$ Ed Saunders, 2012.

[3] Image captured and colorized at NIAID's Rocky Mountain Laboratories (RML) in Hamilton, Montana, em https://www.flickr.com/photos/niaid/49534865371/in/album-72157712914621487 (acedido em 09/06/2020).

[4] B. Oberfeld, A. Achanta, K. Carpenter, P. Chen, N. M. Gilette, P. Langat, Cellaceite (2020), disponível online: doi.org/ 10.1016/j.cell.2020.04.013.

[5] J. Israelachvili, "Intermolecular and Surface forces", $2^{\text {nd }}$ Ed, Academic Press, San Diego, EUA, 1998.

[6] P. Reynolds, Wetting of Surfaces, 197-218, em T. Cosgrove (Ed.) Colloid Science: Principles, Methods and Applications, $2^{\text {nd }}$ Ed John Wiley \& Sons, Chichester, UK (2010).

[7] A. El Khyat, A. Mavon, M. Leduc, P. Agache, P. Humbert, Skin Research and Technology 2 (1996) 91-96.

[8] J. Krawczyk, Skin Research and Technology (2014) 1-10.

[9] G. Vazquez, E. Alvarez, J. Navaza, J. Chem. Eng. Data 40 (1995) 611-614.

[10] N. van Doremalen, T. Bushmaker, D. H. Morris, M. G. Holbrook, A. Gamble, B. N. Williamson, A. Tamin, J. L. Harcourt, N. J. Thornburg, S. I. Gerber, J. O. Lloyd-Smith, E. de Wit, V. J. Munster, The N Engl. J. Med. 382 (2020) 1564-1567.
Maria da Soledade C. S. Santos

Professora Auxiliar do Departamento de Química e Bioquímica da Faculdade de Ciências da Universidade de Lisboa coordenando, atualmente, $01{ }^{\circ}$ Ciclo em Química Tecnológica. Desenvolve investigação científica no Centro de Química Estrutural na área da Química-Física de soluções e sistemas coloidais. mssantos@ciencias.ulisboa.pt ORCID.org/0000-0002-3269-1278. 